of bronze knives, spear-heads and bracelets, gold ornaments and pottery acquired by Sir Leonard Woolley in his excavations at Atchana in Syria, including pottery imported from Cyprus and Mycenæ, as well as local ware of about 1650-1450 B.c. in imitation of Cretan pottery of Minoan type. The National Art Collections Fund has given a slab from the stone balustrade of a staircase of the palace at Persepolis, dating from the reign of Darius the Great or Xerxes, somewhere between 520 and 460 B.c. It is carved in relief with the figure of a human-headed lion, winged and wearing a horned headdress. The Christy Trustees have presented a fine and important group of Peruvian pottery from the southern coastal area of Peru in the neighbourhood of Nasca. This Nasca ware, now thought to date from about 200 B.c. to A.D. 200 is an early, though not the earliest, form of Peruvian prehistoric pottery, and is distinguished by the variety of colouring and the fineness of line of its painted decoration.

\section{Television Receivers}

IN the General Electric Co.'s (G.E.C.) Journal of May and August a description is given by D. C. Espley and G. W. Edwards of television receivers made by the G.E.C. and how they have withstood the tests to which they have been subjected. Since the Commission, formed in May 1934, considered the position of television as a public service, it has come very much to the front. The Commission decided that the standard picture should not be less than 240 lines, with 25 frames per second as the repetition frequency. They further recommended that work should be started on an experimental transmitting station with a 450 line 50 frame per second. The G.E.C. Research Laboratories concentrated, therefore, on the forthcoming transmissions from the Alexandra Palace. It was originally expected that this transmitter would provide good signals within a circular area of 25 miles radius. Results with the receivers have exceeded expectations. At Reading (39 miles), Tunbridge Wells (38 miles), Maidstone (38 miles), Farnham (42 miles) and Brighton (56 miles) the results are entirely satisfactory. Using a modified set, it was found possible to obtain a well-synchronized picture at the G.E.C. Radio Works at Coventry (80 miles), although at this distance the appreciable 'background' noise must produce visible effects on the picture. Apart from the effects of local irregularities, it is now stated that the field strength round the transmitter has an almost circular distribution. The small irregularities are generally due to shadows produced by the proximity of buildings and the contour of the hills. In a few cases it was found necessary to erect aerials with directional properties either for raising low field strength or to avoid local interference when it is excessive.

\section{Agricultural Advice}

THE Harper Adams Agricultural College, Newport, Shropshire, has issued a review of its advisory work in the West Midland province during 1936-37 (Adv. Rept. No. 12, pp. 23, May 1937). This is contributed by the advisory staff of the College, and bears the title of "Harper Adams Adviser". Topics of special interest are described, and the most significant tendencies are shown, but no attempt is made to condense the whole advisory activity into this small volume. Mr. F. S. Dennis shows, among other things, the high cost of milk production in Warwickshire, and indicates the lines of heavy expenditure. The correction of heart-rot in sugar beet, and 'Raan' in swedes, by the application of borax, is one interesting feature of Mr. W. Morley Davies's contribution, and the yield of milk deficient in butter-fat and total solids during spring and early summer also receives attention. This is a question vital to dairy farmers, for many cows do not provide milk which reaches the necessary legal standards at this period. "Some Causes of Winter Wheat Failure" is the main topic of Mr. H. C. F. Newton, the advisory entomologist, whilst Mr. N. C. Preston discusses the fungus disease of the same crop, known by the laconic name 'takeall'. Dr. A. Lloyd Provan compares the simple methylene blue test for the number of bacteria in milk, with the more accurate, but cumbersome, plating method. Veterinary investigational work is described by Mr. K. D. Downham.

\section{Australian Science Abstracts}

THE Australian National Research Council performs a useful service to its territorial men of science, and to a larger body of workers, by the publication of Australian Science Abstracts. This appears quarterly. (Subscription 4s. per annum, post paid, from the Editor-in-Chief, Australian Museum, College Street, Sydney.) Sections are devoted to agriculture, anthropology, botany and forestry, chemistry, economics and statistıcs, engineering, geography, geology, physics, physiology, veterinary science, and zoology. Papers on research findings or communications of general scientific significance are cited, and a short abstract follows most of the titles. Mr. T. Hodge-Smith is the editor-inchief, and has the assistance of ten honorary abstractors. It is often difficult for the worker in Great Britain to follow research at the Antipodes, but this publication should make such contact possible.

\section{The Reinmuth Earth-grazing Planet, I937 UB}

THIs object was discovered by Herr K. Reinmuth at Königstuhl on Oct. $28^{\mathrm{d}} 22^{\mathrm{h}} 27 \cdot 6^{\mathrm{m}}$ U.T., near - Piscium. Its magnitude was estimated to be 10 , but 24 hours later the magnitude was 8 , an indication of rapid approach to the earth. As it moved nearly one hour in R.A. in this time, it was obviously fairly close to the earth. Herr Schewick at Sonneberg found images of it on four plates, from October 26 to 29 , and orbits were computed from the results. Unfortunately, the short interval rendered the determination of the period very uncertain, and this was found to range between $1 \cdot 1$ and about 4 years. The other elements were computed with as close agreement as could be expected from the data, and the various orbits indicated a small inclination to the 
plane of the ecliptic-about $6^{\circ}$. On October 31 it made its closest approach to the earth, passing within 400,000 miles-the nearest approach of any minor planet. It reached perihelion about the middle of December, its distance from the sun being then 0.6 unit, that is, $56,000,000$ miles. At present it is nearly 1 unit from the sun and about 1.5 units from the earth.

I $T$ is certain that no accurate determination of the time of revolution around the sun is possible from observations over four days, and it is very improbable that it will be seen at the next return, unless by a most fortunate coincidence. Dr. M. Davidson described his computation of the orbit of $1932 \mathrm{HA}$ at the Royal Astronomical Society in May 1932, and predicted that other planets of a similar character, making close approaches to the earth, would be discovered. Since May 15, 1932, when this planet approached the earth within 7 million miles, Adonis came within $1 \frac{1}{2}$ million miles in 1936, and now 1937 UB has made a closer approach than either. It is fairly safe to infer that there is a family of these small bodies, their diameter not exceeding 1-2 miles, the orbits of which lie well within the orbit of the earth, and that more of them will be discovered. Probably in the past the earth encountered many of them, but the craters formed, assuming that some of them struck the ground, not the ocean, have been obliterated in the vicissitudes of geological ages. It may be conjectured that our planet has swept up all that could possibly encounter it, for which reason a collision with one of these small bodies is an extremely remote possibility. It is hoped that some light will be thrown on problems of cosmogony through the study of these small planets.

\section{The Night Sky in January}

THE planets visible in the south-west sky in the evening are Mars and Saturn, and the approach of the former towards the latter will be noted, until, by February 2, Mars will have passed eastwards of Saturn. On January 20, Mercury is at greatest elongation (24. west) and may possibly be seen about $5^{\circ}$ above the south-east horizon on that date at $7 \mathrm{~h}$. In the middle of the month, Sirius souths at $23^{\mathrm{h}}$ and is one of a conspicuous array of first magnitude stars to be seen southwards near the meridian. In order of apparent magnitude these stars are Sirius $\left(-1 \cdot 6^{\mathrm{m}}\right)$, Capella $\left(0 \cdot 2^{\mathrm{m}}\right)$, Rigel $\left(0 \cdot 3^{\mathrm{m}}\right)$, Procyon $\left(0 \cdot 5^{\mathrm{m}}\right)$, Betelgeuse $\left(0.9^{\mathrm{m}}\right.$, variable), Aldebaran $\left(1 \cdot 1^{\mathrm{m}}\right)$ and Pollux $\left(1 \cdot 2^{\mathrm{m}}\right)$. Two of these stars offer extreme examples of stellar densities. There is Betelgeuse, a super-giant star with a diameter of about 250 million miles, the average density of which is one-millionth that of water. In contrast, the companion of Procyon, an extremely dense white-dwarf star of planetary dimensions, has a mean density more than a million times that of water.

\section{Announcements}

Prof. Niels BoHr, professor of physics in the University of Copenhagen, and Prof. Georges Denigès, formerly professor of biological chemistry in the
University of Bordeaux, have been elected Correspondants of the Sections of General Physics and Chemistry, respectively, of the Paris Academy of Sciences.

THE honorary membership of the Royal Asiatic Society has been conferred upon Prof. René Dussaud, Secrétaire perpetuel de l'Académie des Inscriptions et Belles Lettres et Conservateur honoraire des Musées Nationaux, Paris, in recognition of his eminent services to Semitic archæology, history and epigraphy.

Colonel W. B. Purdon, professor of hygiene at the Royal Army Medical College, is to be promoted Major-General and will take over the office of commandant and director of studies at the College in March. He will succeed Major-General W. P. MacArthur, who will assume the appointment of director-general of the Army Medical Service on that date. The new professor of hygiene will be Lieut. Colonel D. I. Richardson, at present assistant director of hygiene, the War Office.

The University of Basle has conferred honorary doctorates on Profs. Paul Karrer and Leopold Ruzicka, who hold the chairs of chemistry at the University and Polyclinic at Zurich respectively. The former has investigated the structure of vitamins $A$ and B, and the latter the structure of the sterols including vitamin $\mathrm{D}$ and the sex hormones.

THE following appointments and promotions in the Colonial Service have recently been made: Colonial Forest Service: A. R. Barrie (Malaya), J. S. P. Beard (Trinidad), H. A. Douglas (Gold Coast), D. C. Duff (Gold Coast), E. S. Erskine (Malaya), D. B. Fanshawe (British Guiana), F. P. Graves (Malaya), J. H. Nelson Smith (British Guiana); E. Davies, inspector of produce, Nigeria; R. F. Innes, assistant agricultural chemist, Jamaica ; B. C. King, chemist and petrologist, Uganda; D. Sturdy (agricultural officer), senior agricultural officer, Tanganyika ; Capt. W. S. Aitken, senior veterinary officer, Uganda; Dr. J. Carmichael, senior veterinary research officer, Uganda; R. J. Simmons, senior veterinary officer, Uganda; J. R. V. Smyth, senior agricultural superintendent, Agricultural Chemists' Branch, Jamaica.

A LIST of whole-time awards for scientific research, other than professorships, offered by public and private bodies in Great Britain and Northern Ireland has recently been issued by the Royal Commission for the Exhibition of 1851 (1 Lowther Gardens, Exhibition Road, London, S.W.7. Price 1s.). The list comprises fellowships, studentships, scholarships, etc., classified into: $(A)$ open awards offered by private and public bodies other than universities or colleges; $(B)$ open awards offered by universities or colleges; (C) awards restricted to candidates from particular localities or institutions. Particulars concerning each award are given. The list contains much valuable information, and should be kept at hand by heads of research departments and institutions. 